\title{
An epizoological study of wastage in Thoroughbred racehorses in Gauteng, South Africa
}

\author{
A Olivier ${ }^{a}$, J P Nurton ${ }^{b}$ and A J Guthrie ${ }^{b}$
}

\begin{abstract}
Wastage is the term used to describe the phenomenon of the loss of racehorses from conception to adulthood due to death or injuries (i.e. they never reach a race-track), or the days lost by racehorses due to not training or being withdrawn from a race. This epizoological study was conducted to investigate wastage in Thoroughbred horses used for flat racing in the Gauteng Province of South Africa. Data from 6 racing stables were recorded from 1 March 1993 to 28 February 1994. Each trainer completed a daily training record of the horses in his stable. This questionnaire included reasons why a horse failed to train on a specific day, or was withdrawn from a race. During the year, 8480 days (8.1\%) of the 105108 total potential training days were lost by horses in the stables investigated. Of the days lost, $72.1 \%$ were due to lameness, $8.6 \%$ to respiratory problems, and $19.3 \%$ to other causes. The lost training days for the individual trainers ranged from 5.4 to $12.6 \%$. Of the 579 horses included in the study, 291 horses $(50.3 \%$ ) lost one or more training days; 541 problems resulting in wastage were found in these 291 horses; $263(48.6 \%)$ cases were due to lameness and $49(9.0 \%)$ were caused by coughing. The balance were caused by poor weather conditions $(11.3 \%)$, vaccinations $(7.2 \%)$, wounds $(4.6 \%)$, abnormal haematology results $(1.8 \%)$, inappetence $(2.2 \%)$, nasal discharge $(2.0 \%)$, epistaxis $(1.8 \%)$, babesiosis $(1.8 \%)$, miscellaneous other conditions $(7.9 \%)$ and unknown causes $(1.8 \%)$. An attempt was made to continue the study for a 2nd year but too few questionnaires were returned. However, it was evident that the percentage of lost training days $(8.2 \%)$ was similar to that of the previous year. The training days lost due to lameness $(66.9 \%)$ and respiratory problems $(8.4 \%)$ were also similar to those of the previous year. From the findings of the present study, it was concluded that lameness and respiratory disorders were the major causes of wastage in Thoroughbred racehorses in Gauteng. Further research into these causes of wastage in racehorses is needed.
\end{abstract}

Key words: Gauteng, racehorse, racing, South Africa, Thoroughbred, training days, wastage.

Olivier A, Nurton J P, Guthrie A J An epizoological study of wastage in Thoroughbred racehorses in Gauteng, South Africa. Journal of the South African Veterinary Association (1997) 68(4): 125-129 (En.). Department of Surgery, Faculty of Veterinary Science, University of Pretoria, Private Bag X04, Onderstepoort, 0110 South Africa.

\section{INTRODUCTION}

Epizoological studies investigating wastage in racehorses have been performed in Newmarket, United Kingdom ${ }^{15}$ and in Cologne, Germany ${ }^{4,8}$. A study comparing the exercise level and problem rate of Thoroughbreds was also conducted at Canterbury Downs in Minnesota (USA) ${ }^{7}$. Jeffcott $e t$ al. ${ }^{6}$ assessed wastage in Thoroughbred racing from conception to 4 years of age. The career profile of Canadian Standardbreds,

${ }^{a}$ Department of Surgery, Faculty of Veterinary Science University of Pretoria, Private Bag X04, Onderstepoort, 0110 South Africa.

${ }^{b}$ Equine Research Centre, Onderstepoort, 0110 South Africa.

Received: April 1997. Accepted: August 1997. reviewing the influences of age, gait and sex on the chances of racing, money won, the number of races, race times and temporary absence from racing and season, has also been published ${ }^{11-13}$. Mohammed et al. ${ }^{9}$ reported on risk factors associated with injuries in Thoroughbred horses raced on New York Racing Association tracks.

The financial implications of Thoroughbred racehorses being unable to train or being withdrawn from a race are considerable to the racing industry. For this reason and for the well-being of the horse, it is important to obtain information about the incidence and causes of wastage. This information is invaluable in addressing the problem of wastage, assigning research priorities and attempting to minimise the incidence of wastage.

Since no data on the incidence of wastage in South Africa were available, it was decided to perform this study. It was conducted on similar lines to a previous study performed by Rossdale et al. ${ }^{15}$ in the United Kingdom. In contrast to the United Kingdom and North America, flat racing in South Africa is conducted throughout the year. Most racing in South Africa is on grass and rainfall is seasonal. The training of horses in the present study occurred on sand tracks of various densities; horses were given the opportunity to use the grass tracks for a gallop before a race day.

Six trainers in Gauteng were given questionnaires to complete over a 2-year period to determine the extent and causes of wastage in the South African Thoroughbred racing industry in the Gauteng Province.

\section{MATERIALS AND METHODS}

\section{Database}

Nineteen trainers in Gauteng Province, South Africa, were requested to participate in this study. Only 6 trainers who were willing to participate, returned completed questionnaires on a regular basis. The data from these training stables were used in the study. The stables were designated A-F respectively. Stable A was at Turffontein (south of Johannesburg); Stables B and E were at North Rand Training Centre (approximately halfway between Pretoria and Johannesburg); Stable C was located in Newmarket (east of Johannesburg); Stables D and F were located at Ascot-on-Vaal (near Vereeniging). Data were collected from 1 March 1993 to 28 February 1995. The study was divided into Year 1, which lasted from 1 March 1993 to 28 February 1994, and Year 2, which lasted from 1 March 1994 to 28 February 1995. Table 1 shows the number of horses in the survey by trainer in Years 1 and 2 respectively, as well as a breakdown of the ages of horses in each trainer's stables during data collection. 
Table 1: Number of horses according to age in 6 Gauteng training stables included in the survey (1993-1995).

\begin{tabular}{|c|c|c|c|c|c|c|c|c|c|c|c|c|c|}
\hline \multirow{2}{*}{\multicolumn{2}{|c|}{ Age in years: 1}} & \multicolumn{3}{|c|}{ March 93 - July 93} & \multicolumn{3}{|c|}{ August 93 - February 94} & \multicolumn{3}{|c|}{ March 94 - July 94} & \multicolumn{3}{|c|}{ August 94 - February 95} \\
\hline & & 2 & 3 & $\geq 4$ & 2 & 3 & $\geq 4$ & 2 & 3 & $\geq 4$ & 2 & 3 & $\geq 4$ \\
\hline$A^{a}$ & 7 & 29 & 34 & 14 & 27 & 33 & 41 & 43 & 33 & 28 & 0 & 55 & 47 \\
\hline B & - & - & - & - & 30 & 24 & 21 & 24 & 18 & 14 & - & - & 一 \\
\hline C & 0 & 25 & 18 & 8 & 13 & 20 & 19 & - & - & - & 0 & 21 & 23 \\
\hline D & 0 & 30 & 21 & 15 & 16 & 31 & 19 & 29 & 28 & 10 & 0 & 28 & 28 \\
\hline$E$ & 9 & 30 & 24 & 16 & 15 & 34 & 30 & - & - & - & - & - & - \\
\hline $\mathrm{F}$ & 4 & 35 & 15 & 9 & 43 & 32 & 13 & 21 & 24 & 4 & - & - & - \\
\hline Total & 20 & 149 & 112 & 62 & 144 & 174 & 143 & 117 & 103 & 56 & 0 & 104 & 98 \\
\hline
\end{tabular}

${ }^{\mathrm{a}} \mathrm{A}-\mathrm{F}=$ individual training stables.

The average monthly rainfall, temperature and humidity were recorded, by obtaining data from the South African Weather Bureau from weather stations nearest to the training tracks. Seasonal means of these data were calculated for summer (December-February), autumn (March-May), winter (June-August) and spring (September-November).

\section{Method of obtaining data}

The trainer or trainer's assistant completed a questionnaire on horse-related or other conditions leading to wastage or withdrawing a horse from a race. The questionnaire was completed for every horse that was withdrawn from a race or did not train according to each trainer's routine training programme for one or more of the reasons listed in Table 2. Data were also collected on the probable causes of lameness and respiratory problems.

\section{Decision-making}

The ultimate decision to not train a horse or withdraw it from a race rested with the individual trainers. Most diagnoses for not training a horse were made by the trainers; few were confirmed by veterinarians. Diagnoses for withdrawal from a race were made by the veterinarian who issued the withdrawal certificate.

\section{Days in training or not-in-training}

A day not-in-training was defined as a day on which the horse was not sent to the training track to work for reasons of injury, disease or other. Sundays and public holidays were not included as days missed if these days were routinely regarded as rest days by the individual trainer.

\section{Data analysis}

The effect of horse age and season on the incidence of lameness and respiratory tract problems in Year 1 was determined

Table 2: Conditions included in questionnaire given to trainers for which horses were not trained on a specific day or scratched from a race.

Coughing
Nasal discharge
Epistaxis
Skin conditions
Inappetence
Colic
Lameness
Wounds
Fever
Heart conditions
Biliary
Cytological and/or blood chemistry aberrations
Bad track or weather conditions
Labour problems
Other conditions

using Chi-square analysis $\left(\mathrm{SAS}^{\oplus}\right.$ version 5 , SAS Institute, Cary, USA) with $p \leq 0.01$. A log linear analysis was conducted to identify specific combinations where the condition (lameness or respiratory) and incidence rendered significantly high or low observed frequencies (StatGraphics ${ }^{\circledR}$ v. 5, Bitstream, Cambridge, Massachusetts, USA). A finding was considered significant if $p \leq 0.01$

\section{RESULTS}

\section{First year}

Table 3 summarises the incidence of days lost per training yard. During the 1st year, 8480 days $(8.1 \%)$ of the 105108 total potential training days were lost by the 6 stables investigated. Of the days lost, $72.1 \%$ were due to lameness, $8.6 \%$ were due to respiratory problems and $19.3 \%$ were due to a variety of other causes. The horses with respiratory conditions showed one or more of the following symptoms: coughing, nasal discharge, pharyngitis, epistaxis and upper respiratory noises.

Of the 579 horses included in the study,
291 horses $(50.3 \%)$ lost 1 or more training days; 541 problems resulting in wastage were found in these 291 horses; 263 of these problem cases $(48.6 \%)$ were due to lameness and $49(9.0 \%)$ were caused by respiratory problems (coughing, epistaxis or nasal discharge). The balance were caused by poor weather conditions $(11.3 \%)$, vaccinations $(7.2 \%)$, wounds $(4.6 \%)$, abnormal haematology results $(1.8 \%)$, inappetence $(2.2 \%)$, nasal discharge $(2.0 \%)$, epistaxis $(1.8 \%)$, babesiosis $(1.8 \%)$, miscellaneous other conditions $(7.9 \%)$ and unknown causes (1.8\%).

The data on the causes of lameness were not included in this study owing to the absence of confirmation by a veterinarian or because more than one cause of lameness was cited by the trainer in an extended convalescence time period. The lost training days for the individual trainers ranged from 5.4 to $12.6 \%$. The percentage of wastage in each trainer's stable ranged from $0.1 \%$ to $23.7 \%$ of the total number of horses in their stables during the year, with an average of $12.8 \%$. 
Table 3: Days in training and days wasted due to lameness, respiratory problems and other conditions in $1993 / 94$ in 6 training stables in Gauteng.

\begin{tabular}{|c|c|c|c|c|c|c|c|}
\hline & $\begin{array}{c}\mathbf{A}^{\mathrm{a}} \\
\text { Turffontein }\end{array}$ & $\begin{array}{c}\text { B } \\
\text { North Rand }\end{array}$ & $\begin{array}{c}\text { C } \\
\text { Newmarket }\end{array}$ & $\begin{array}{c}\text { D } \\
\text { Vaal }\end{array}$ & $\begin{array}{c}\text { E } \\
\text { North Rand }\end{array}$ & $\begin{array}{c}\mathbf{F} \\
\text { Vaal }\end{array}$ & Total \\
\hline $\begin{array}{l}\text { Number of days in training } \\
\text { Number of days lost }\end{array}$ & $\begin{array}{c}28226 \\
1952 \\
(6.9)^{b}\end{array}$ & $\begin{array}{c}8862 \\
488 \\
(5.5)\end{array}$ & $\begin{array}{c}13580 \\
1709 \\
(12.6)\end{array}$ & $\begin{array}{c}16389 \\
880 \\
(5.4)\end{array}$ & $\begin{array}{c}15240 \\
1567 \\
(10.3)\end{array}$ & $\begin{array}{c}22811 \\
1884 \\
(8.3)\end{array}$ & $\begin{array}{c}105108 \\
8480 \\
(8.1)\end{array}$ \\
\hline Lameness & $\begin{array}{c}1509 \\
{[81.4]^{\mathrm{c}}}\end{array}$ & $\begin{array}{c}206 \\
{[42.2]}\end{array}$ & $\begin{array}{c}1505 \\
{[88.1]}\end{array}$ & $\begin{array}{c}475 \\
{[54.0]}\end{array}$ & $\begin{array}{c}961 \\
{[61.3]}\end{array}$ & $\begin{array}{l}1381 \\
{[73.3]}\end{array}$ & $\begin{array}{l}6118 \\
{[72.1]}\end{array}$ \\
\hline Respiratory & $\begin{array}{c}103 \\
{[5.3]^{c}}\end{array}$ & $\begin{array}{c}8 \\
{[1.6]}\end{array}$ & $\begin{array}{c}71 \\
{[4.2]}\end{array}$ & $\begin{array}{c}95 \\
{[10.8]}\end{array}$ & $\begin{array}{l}361 \\
{[23]}\end{array}$ & $\begin{array}{c}94 \\
{[5.0]}\end{array}$ & $\begin{array}{l}732 \\
{[8.6]}\end{array}$ \\
\hline Other & $\begin{array}{c}259 \\
{[13.3]^{\mathrm{c}}}\end{array}$ & $\begin{array}{c}274 \\
{[56.2]}\end{array}$ & $\begin{array}{c}133 \\
{[7.8]}\end{array}$ & $\begin{array}{c}310 \\
{[35.2]}\end{array}$ & $\begin{array}{c}245 \\
{[15.6]}\end{array}$ & $\begin{array}{c}409 \\
{[21.7]}\end{array}$ & $\begin{array}{c}1630 \\
{[19.2]}\end{array}$ \\
\hline
\end{tabular}

${ }^{\mathrm{a}} \mathrm{A}-\mathrm{F}=$ individual training stables.

${ }^{b}$ Numbers in round brackets $=$ percentage of training days lost out of total days in training.

${ }^{\mathrm{C}}$ Numbers in square brackets = percentage of training days lost due to lameness, respiratory or others reasons out of total days lost.

Table 4: Effect of season on days wasted due to the incidence of lameness and respiratory problems in Year 1 (comparison of observed vs. expected frequency).

\begin{tabular}{lcccc}
\hline & $\begin{array}{c}\text { Summer } \\
\text { (December-February) }\end{array}$ & $\begin{array}{c}\text { Autumn } \\
\text { (March-May) }\end{array}$ & $\begin{array}{c}\text { Winter } \\
\text { (June-August) }\end{array}$ & $\begin{array}{c}\text { Spring } \\
\text { (September-November) }\end{array}$ \\
\hline Lameness: observed frequency & 64.00 & $112.00^{*}$ & 83.00 & $71.00^{*}$ \\
Lameness: expected frequency & 70.40 & 81.14 & 82.89 & 95.57 \\
Respiratory problem: observed frequency & 7.00 & 17.00 & $21.00^{*}$ & 8.00 \\
Respiratory problem: expected frequency & 11.31 & 13.03 & 13.31 & 15.35 \\
\hline
\end{tabular}

*Significant: $p \leq 0.01$

Table 5: Effect of age on days wasted due to the incidence of lameness and respiratory conditions in horses in Year 1 (comparison of observed vs. expected frequency).

\begin{tabular}{lcccc}
\hline Age in years: & 2 years & 3 years & 4 years & 5 years \\
\hline Lameness: observed frequency & $54.00^{*}$ & $120.0^{*}$ & 51.00 & 16.00 \\
Lameness: expected frequency & 90.90 & 86.7 & 46.41 & 16.96 \\
Respiratory problem: observed frequency & 21.00 & $18.00^{*}$ & $12.00^{*}$ & 2.000 \\
Respiratory problem: expected frequency & 33.15 & 8.29 & 5.37 & 6.187 \\
\hline
\end{tabular}

*Significant: $p \leq 0.01$.

The effect of season (summer, autumn, winter and spring) on the incidence of lameness and respiratory tract conditions in Year 1 is shown in Table 4. The effect of age of the horse on the incidence of lameness and respiratory tract conditions in Year 1 is shown in Table 5. The number of training days lost due to lameness was significantly higher in autumn and significantly lower in spring. The number of training days lost due to respiratory problems was significantly higher in winter. The occurrence of lameness was significantly higher in 3-year-olds and significantly lower in 2-year-olds. The number of training days lost due to respiratory problems was significantly higher than expected in 3- and 4-year-olds.

The mean monthly rainfall for each month, grouped into season, the mean minimum and maximum seasonal temperatures and mean seasonal relative humidity, recorded at weather stations nearest to the training tracks during Year 1 are illustrated in Fig. 1. The highest average rainfall exceeded $100 \mathrm{~mm}$ in spring and summer and was lowest in winter. The average maximum temperature exceeded $25{ }^{\circ} \mathrm{C}$ in spring and summer. The average minimum temperature was less than $5{ }^{\circ} \mathrm{C}$ in winter. The mean relative humidity ranged between approximately 40 and $60 \%$ in winter and summer respectively.

\section{Second year}

The present study was continued in 1994/95. Numbers of days and horses were not added to the 1st year's results due to a marked decrease in the return of questionnaires from the trainers (Table 6). However, it was evident that the percentage of the training days lost $(8.2 \%)$ was similar to that of the previous year. The number of training days lost due to lameness $(66.9 \%)$ and respiratory problems $(8.4 \%)$ was also similar to the previous year. 
Table 6: Days in training and days wasted due to lameness, respiratory problems and other conditions in $1994 / 95$ in 6 training stables in Gauteng.

\begin{tabular}{|c|c|c|c|c|c|c|c|}
\hline & $\begin{array}{c}\mathbf{A}^{\mathrm{a}} \\
\text { Turfontein }\end{array}$ & $\begin{array}{c}\text { B } \\
\text { North Rand }\end{array}$ & $\begin{array}{c}\text { C } \\
\text { Newmarket }\end{array}$ & $\begin{array}{c}\text { D } \\
\text { Vaal }\end{array}$ & $\begin{array}{c}\text { E } \\
\text { North Rand }\end{array}$ & $\begin{array}{c}\mathbf{F} \\
\text { Vaal }\end{array}$ & Total \\
\hline Number of days in training & 24007 & 3355 & 6558 & 13463 & - & 5905 & 53288 \\
\hline Number of days lost & $\begin{array}{l}2217 \\
(9.2)^{b}\end{array}$ & $\begin{array}{l}283 \\
(8.4)\end{array}$ & $\begin{array}{c}671 \\
(10.2)\end{array}$ & $\begin{array}{l}639 \\
(4.7)\end{array}$ & $\overline{(9.4)}$ & $\begin{array}{l}555 \\
(8.2)\end{array}$ & 4365 \\
\hline Lameness & $\begin{array}{l}1507 \\
{[68.0]^{c}}\end{array}$ & $\begin{array}{c}146 \\
{[51.6]}\end{array}$ & $\begin{array}{c}603 \\
{[89.9]}\end{array}$ & $\begin{array}{c}321 \\
{[50.2]}\end{array}$ & $\overline{61.6]}$ & $\begin{array}{c}342 \\
{[66.9]}\end{array}$ & 2919 \\
\hline Respiratory & $\begin{array}{c}214 \\
{[9.7]^{\mathrm{c}}}\end{array}$ & $\begin{array}{c}23 \\
{[8.1]}\end{array}$ & $\begin{array}{c}6 \\
{[0.9]}\end{array}$ & $\begin{array}{c}100 \\
{[15.7]}\end{array}$ & $\overline{[4.7]}$ & $\begin{array}{c}26 \\
{[8.4]}\end{array}$ & 369 \\
\hline Other & $\begin{array}{c}496 \\
{[22.3]^{\mathrm{c}}}\end{array}$ & $\begin{array}{c}114 \\
{[40.3]}\end{array}$ & $\begin{array}{c}62 \\
{[9.2]}\end{array}$ & $\begin{array}{c}218 \\
{[34.1]}\end{array}$ & {$[\overline{-}$} & $\begin{array}{c}187 \\
{[24.7]}\end{array}$ & 1077 \\
\hline
\end{tabular}

${ }^{\mathrm{a}} \mathrm{A}-\mathrm{F}=$ individual training stables.

${ }^{b}$ Numbers in round brackets = percentage of training days lost out of total days in training.

${ }^{c}$ Numbers in square brackets = percentage of training days lost due to lameness, respiratory or others reasons out of total days lost.

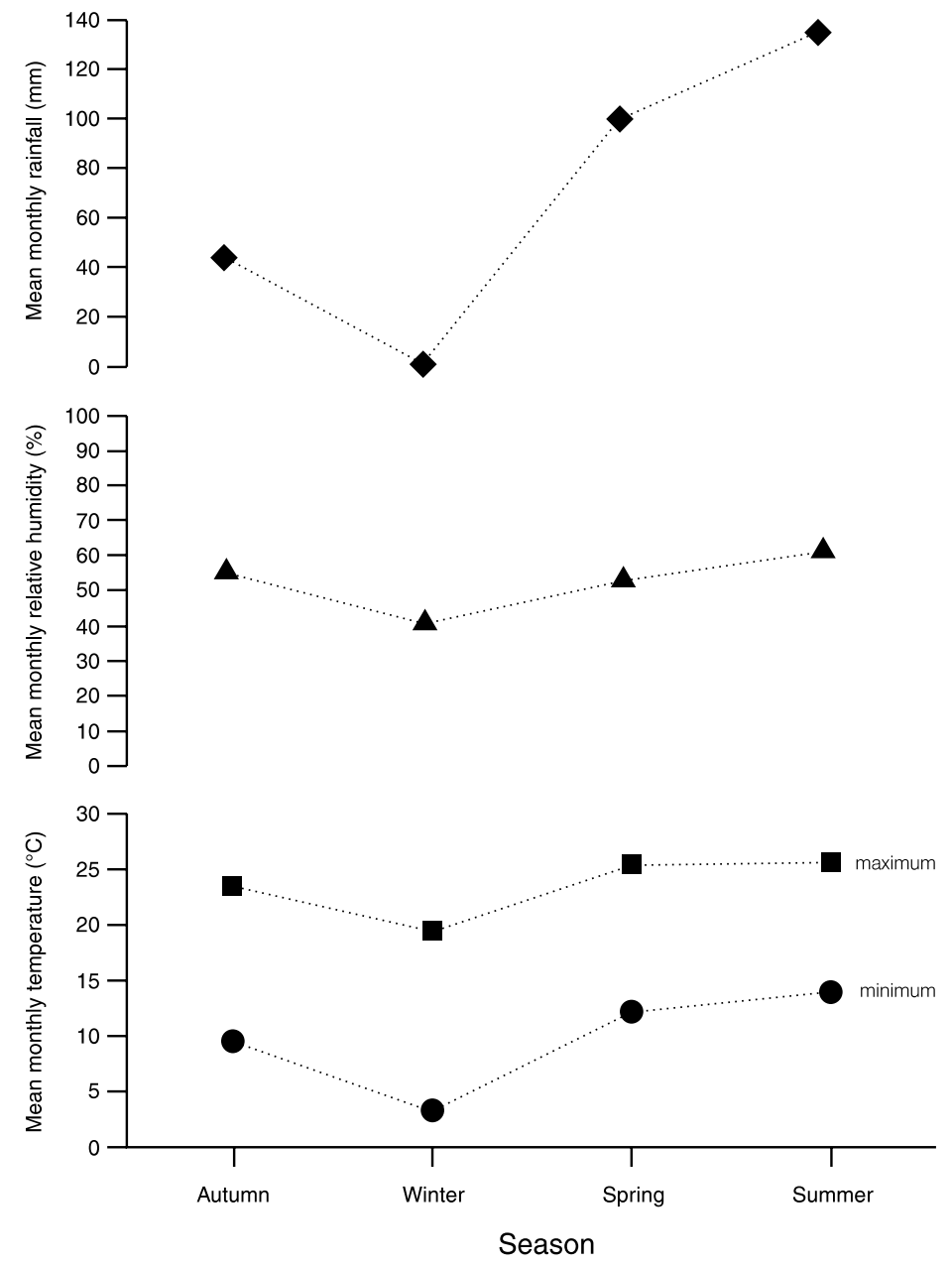

Fig. 1: Mean monthly rainfall for each season, mean minimum and maximum seasonal temperatures and mean seasonal relative humidity, recorded at weather stations nearest to the training tracks during Year 1.

\section{DISCUSSION}

The high percentage of training days lost due to lameness $(72.1 \%)$ is similar to that found by Rossdale et al. ${ }^{15}(67.6 \%)$ and
Jeffcott et al. ${ }^{6}$. In Cologne, musculoskeletal problems were responsible for $55.3 \%$ of wastage or retirement of horses from racing ${ }^{4}$. Lindner and Dingerkus reported a $57 \%$ wastage due to lameness ${ }^{8}$. A similar study by Kobluk et al. described an estimated $44 \%$ of horses having a musculoskeletal problem preventing training or racing for any period of time and an additional estimated $32 \%$ of horses having a musculoskeletal problem altering planned training or racing schedules.

The observed increased incidence of lameness in autumn months may have been due to the relatively low rainfall and temperature (Fig. 1), which could have resulted in hard tracks that could contribute to the development of lameness. Other causes are probably more important, since the mean rainfall and temperature were even lower in winter, and no significant increase in lameness was found. An increase in rainfall resulting in softer sand tracks could possibly account for the significantly lower incidence of lameness in spring. Hill et al. ${ }^{5}$ concluded in their study at New York Racing Association tracks that track conditions, environmental conditions and age of horses are of no importance in the occurrence of racing injuries to Thoroughbred horses. However, they qualified this by stating that injuries suffered during training were not included in their study. Rooney ${ }^{14}$ stated that there is a distinct relationship between the frequency of lameness and temperature and humidity, but found no correlation of lameness incidence with rainfall.

The present study had a relatively low level of wastage due to respiratory problems $(8.6 \%)$ compared to Rossdale et al.'s results of $20.5 \%{ }^{15}$ and Herzog and Lindner's results of $22.6 \%$. This may be due to lower temperatures prevailing for a longer period of time in the United 
Kingdom (UK) as well as the higher humidity in the UK as result of a higher rainfall throughout the year.

The increase in the number of training days lost due to respiratory problems in winter in the present study may be caused by the lower temperatures or poor stable management. During winter, it is common practice to close stables up with the intention of keeping the horses warm, thus affecting ventilation and increasing residual dust ${ }^{10}$. Trainer B (North Rand training centre) was included in the study by Nurton et al. ${ }^{10}$, who found this stable to have the second highest levels of residual dust of the 4 stables studied in the racing centres included in the present study. The stables of trainer B had the lowest percentage of training days lost due to respiratory problems in the present study (Table 3), but since this trainer also had the lowest number of horses in the present study (Table 1), conclusions based on this low number of horses may not be valid.

The effect of age on the low incidence of lameness in 2-year-olds and an increased incidence of lameness in 3-year-olds, can be attributed to many factors. According to the rules of the Jockey Club of Southern Africa, 2-year-olds are not allowed to race before October 1 of the year in which they turn $2^{2}$. This may also account for the lower number of cases of lameness. Trainers may tend to spare the 2-year-olds and push the 3-year-olds harder to perform well.

In the combined 2 racing seasons 1992/3 and 1993/1994, 3663 2-year-olds ran 12857 races, i.e. approximately 3.5 races each; 5307 3-year-olds ran 38372 races, i.e. approximately 7.2 races each; 33754 -yearolds ran 25371 races, i.e. approximately 7.5 races each, and 2564 5-year-olds (and older) ran 16999 races, i.e. approximately 6.6 races each. This lower number of starts in the 2-year-olds may also explain the lower incidence of lameness in this age group. Inherent weaknesses not apparent at 2 years of age may become clinically apparent at 3 years of age. Mohammed et al. ${ }^{13}$ reported that the risk of breakdown of horses in their 2nd, 3rd and 4th seasons of racing decreased 2, 3 and 4 times respectively, compared with horses in their 1st season of racing. Breakdown was defined as a horse that had not raced within 6 months following a musculoskeletal injury on the racetrack. The difference pertaining to 2-year-olds in the present study may have arisen because the study by Mohammed et al. ${ }^{13}$ was based on breakdown during racing, as opposed to training in the present study.

The effect of age on the increased incidence of respiratory problems (3- and 4 -year-olds) may be explained by the fact that, because 3- and 4-year-olds have more starts than 2- or 5-year-olds ${ }^{3}$, they may be travelling more and therefore suffer more exposure to respiratory pathogens than the other age groups. These 3- and 4-year-old horses may also have been stabled with inadequate ventilation, leading to chronic respiratory disease, for relatively longer periods than the 2-year-old horses. With the exception of congenital problems, we have found no reports on age-related upper respiratory problems.

The data here must be related to the type of trainers selected to partake in the study. The trainers included in this study were among the top 44 trainers as reflected by the total stakes earned at Gauteng race-tracks for the 1993/94 season $^{1}$. The success of these trainers may be due to the quality of the horses they train or training methods that differed from those of less successful trainers.

The decreased return of questionnaires in Year 2 precluded statistical analysis, but the trends were similar (Table 6) and suggest that results for the 2 years may have been comparable.

From these data it is concluded that lameness and respiratory conditions were the 2 most important causes of wastage in Thoroughbred racehorses in Gauteng, South Africa, in 1993/94. Continued research should be conducted to increase our knowledge of the reasons for the occurrence of these conditions in order to prevent them and minimise their effect on Thoroughbred racing in South Africa.

\section{ACKNOWLEDGEMENTS}

We thank all the trainers who participated in this study; without their cooperation this project would not have been possible. We also thank the Equine Research Centre at Onderstepoort for funding the project. Special thanks are also due to Prof. C F Smit from STATOMET, University of Pretoria, for help with statistical analysis.

\section{REFERENCES}

1. Anon. 1994 Highveld trainer $\log$ at all Highveld courses in sequence of stakes earned from 1st August 1993 to 30th July 1994. Computaform Vaal Race Course: 18

2. Anon. 1995 The rules of the Jockey Club of southern Africa. Jockey Club of Southern Africa, Turffontein

3. Anon. 1997 Department of data processing. Jockey Club of Southern Africa, Turffontein

4. Herzog von B, Lindner A 1992 Haufigkeit und Ursachen für Trainingsausfall und für das Ausscheiden aus dem Sport bei Galpprennpferden. Tierärztliege Umschau 47: 486-490

5. Hill T, Carmichael D, Maylin G, Crook L 1986 Track condition and racing injuries in Thoroughbred horses. Cornell Veterinarian 76: 361-379

6. Jeffcott L B, Rossdale P D, Freestone J, Frank C J, Towers-Clarke P F 1982 An assessment of wastage in Thoroughbred racing from conception to four years of age. Equine Veterinary Journal 14: 185-198

7. Kobluk C N, Robinson R A, Clanton C J, Trent A M, Ames T R, Gordon B J 1990 Comparison of the exercise level and problem rate of 95 Thoroughbred horses: a cohort study. Proceedings of the 36th Annual Convention of the American Association of Equine Practitioners, 2-5 December 1990: 471-475

8. Lindner A, Dingerkus A 1993 Incidence of training failure among Thoroughbred horses at Cologne, Germany. Preventative Veterinary Medicine 16: 85-94

9. Mohammed H O, Hill T, Lowe J 1991 Risk factors associated with injuries in Thoroughbred horses. Equine Veterinary Journal 23: 445-448

10. Nurton J P, Guthrie A J 1995 Quantification of dust in selected racing stables and on associated training tracks in the Transvaal. Proceedings of the 27th Annual Congress of the Equine Practitioner's Group, Golden Gate, 1316 February 1995: 17

11. Physick-Sheard P W 1986 Career profile of the Canadian Standardbred I. Influence of age, gait and sex upon chances of racing. Canadian Journal of Veterinary Research 50: 449-456

12. Physick-Sheard P W 1986 Career profile of the Canadian Standardbred II. Influence of age, gait and sex upon number of races, money won and race times. Canadian Journal of Veterinary Research 50: 457-470

13. Physick-Sheard P W, Russell M 1986 Career profile of the Canadian Standardbred III. Influence of temporary absence from racing and season. Canadian Journal of Veterinary Research 50: 471-478

14. Rooney J R 1982 The relationship of season of the year to lameness and breakdown in thoroughbred race horses. Journal of Equine Veterinary Science 2: 174-176

15. Rossdale P D, Hopes R, Wingfield Digby N J, Offord K 1985 Epidemiological study of wastage among racehorses 1982 and 1983. The Veterinary Record 116: 66-69 